\title{
Different Responsiveness to Progesterone for Induction of Pseudopregnancy between the First and the Third Estrous Cycle after Vaginal Opening in Rats
}

\author{
Hiroshi Tomogane and Akira Yoкоyama \\ Department of Animal Science, School of Agriculture, Nagoya University, Chikusa, Nagoya 464-01, Japan
}

(Accepted for publication May 16, 1990)

\begin{abstract}
Summary. Effects of progesterone on the function of corpus luteum in estrous cycle were compared between the first and the third estrous cycle after vaginal opening in rats. When 2.5 $\mathrm{mg} / 100 \mathrm{~g}$ body weight (B.W.) progesterone was administered between 07:00 and 08:00 $\mathrm{hr}$ on the day of estrus or on day 1 of diestrus to rats showing the first estrous cycle, the diestrous period was persisted more than 9 days in $95 \%$ of animals. In the diestrous period, plasma prolactin (PRL) level showed daily changes and corpora lutea became functional. The luteal function was enhanced by the deciduoma formed after uterine traumatization on day 3 of diestrus. However, in rats showing the third estrous cycle, $7.5 \mathrm{mg} / 100 \mathrm{~g} \mathrm{~B}$.W. progesterone was required to induce similar response to those obtained in the first estrous cycle. Also, no functional corpora lutea and no daily change in PRL secretion were observed in rats injected with progesterone on day 1 of diestrus in the third estrous cycle. These results indicate that progesterone acts more effectively for induction of pseudopregnant diestrus in the first estrous cycle than in the third estrous cycle.

KEY WORDS: PSEUDOPREGNANCY, PROGESTERONE, PROLACTIN, PUBERTAL RAT
\end{abstract}

Jpn J Anim Reprod 36, 176-183, 1990

In adult cyclic rats, the corpus luteum has not become functional, unless the cervical stimulus is given. However, about a half of immature rats maintained leucocytic vaginal smears for more than 9 days after the first spontaneous ovulation without the cervical stimulus (Tomogane et al., 1987). We have also reported that the nocturnal prolactin (PRL) surge was induced more easily in ovariectomized pubertal rats than in ovariectomized adult rats by the implantation of progesterone-containing tubings at the estrous stage (Tomogane and Yokoyama, 1989). These results suggest that circulating progesterone around the periovulatory stage would induce PRL secretion which could relate to the occurrence of the long diestrous period after the first spontaneous ovulation.
If progesterone administration is limited to the early morning of day of estrus in adult cyclic rats, the animal becomes pseudopregnancy (Everett, 1963; Rothchild and Schubert, 1963; Luque and Castro-Vazquez, 1983) and shows daily changes in PRL secretion (de Greef and Zeilmaker, 1978; Murakami et al., 1980). In order to elucidate the participation of progesterone in the initiation of the long diestrous period in the pubertal rats showing the first estrous cycle, the efficiency of progesterone in inducing pseudopregnancy was compared between the first and the third estrous cycle after vaginal opening in rats.

\section{Materials and Methods}

\section{Animals}

Virgin female Wistar-Imamichi strain rats 
bred in our laboratory were used in the first (32-37 days of age, 47 rats; 95-110 g, body weight) and in the third (45-55 days of age, 180-210 g body weight) estrous cycle after vaginal opening. They were housed in individual cages under controlled conditions of light (lights on at 05:00-19:00 hr) and temperature $\left(24 \pm 2^{\circ} \mathrm{C}\right)$. Commercial diet (CE2, Nihon CLEA, Yokohama, Japan) and water were provided ad libitium. In pubertal rats, vaginal opening was checked every morning after 28 days of age. Vaginal smears after vaginal opening were obtained by vaginal lavage with physiological saline every morning until the end of the third estrous cycle, i.e. the fourth vaginal estrous day. The animal room was kept quiet for at least one hour before blood sampling. Animals were decapitated within 15 seconds after removing them from the cages.

Experiment 1. Effects of a single injection of progesterone on the length of the diestrous period

Progesterone (Sigma Chemical Co., St Louis, MO, USA) was subcutaneously administered $(1.25,2.5,5.0$ or $7.5 \mathrm{mg}$ in $0.2 \mathrm{ml}$ sesame oil per $100 \mathrm{~g}$ body weight) between 07:00 and 08:00 h on the day of estrus in the first or the third estrous cycle. In a part of animals, $2.5 \mathrm{mg}$ per $100 \mathrm{~g}$ body weight (B.W.) progesterone was injected between 07:00 and 08:00 hr on day 1, 2 or 3 of diestrus in the first estrous cycle and $7.5 \mathrm{mg}$ progesterone per $100 \mathrm{~g} \mathrm{B.W}$. was injected between 07:00 and 08:00 hr on day 1 of diestrus in the third estrous cycle. The vehicle was administered subcutaneously to the control animal. The first day on which leucocytic vaginal smears appeared after the treatment was designated day 1 of diestrus.

Experiment 2. Effects of traumatization on the function of corpora lutea of pseudopregnant rats induced by progesterone treatment

Progesterone at the dosage of 2.5 and 7.5 $\mathrm{mg}$ per $100 \mathrm{~g}$ B.W. was injected sub- cutaneously into rats between 07:00 and 08:00 hr on either estrous day or day 1 of diestrus in the first and the third estrous cycle. Uterine horns were traumatized between 09:00 and 11:00 hr on day 3 of diestrus and the rats were decapitated on day 9 of diestrus. The uterine horn was exposed through a midventral abdominal incision under ether anesthesia. A suture needle with a silk thread was introduced into the uterine lumen, the thread was looped through the antimesometrial surface, and tied loosely in the form of a loop on the outside of the uterus. Six loops were made at appropriate intervals on each uterine born. In the shamoperated group, uterine horns were exposed and no thread was introduced. Tunk blood was collected into a chilled heparinized glass tube and centrifuged immediately for $10 \mathrm{~min}$ at $1500 \mathrm{~g}$ and $4^{\circ} \mathrm{C}$. Plasma was stored at $-20^{\circ} \mathrm{C}$ until assayed for progesterone. Uteri were removed, deprived of the surrounding tissue and weighed to the nearest $0.5 \mathrm{mg}$.

Experiment 3. Daily changes in PRL secretion on day 2 of long diestrous period induced by progesterone

Progesterone at the dosage of 2.5 and 7.5 mg per $100 \mathrm{~g} \mathrm{B.W}$. was administered subcutaneously between 07:00 and 08:00 hr on either the day of estrus or on day 1 of diestrus in the first or the third estrous cycles. The animals were decapitated and trunk blood was collected at 05:00, 12:00 or 18:00 hr on day 2 of diestrus. Plasma was stored at $-20^{\circ} \mathrm{C}$ until assayed for PRL.

\section{Measurements of Hormones}

Plasma concentration of progesterone was measured by a radioimmunoassay using an antiserum raised in the rabbit against progesterone-3-carboxymethyloxime-BSA

(Teikoku Hormone MFG. Co. Ltd, Kawasaki, Japan), [1, 2, 6, 7,- $\left.{ }^{3} \mathrm{H}(\mathrm{N})\right]$ progesterone (specific activity $96.5 \mathrm{Ci} / \mathrm{mmol}$, New England Nuclear, Boston, MA, USA) and progester- 
one (Sigma) as described previously (Tomogane and Yokoyama, 1989). Each sample $(2.5$ or $10 \mu \mathrm{l})$ was assayed in duplicate. Intra-assay coefficient of variation was $9.8 \%$ at the level of $150 \mathrm{pg} /$ tube. The lowest detectable level in the assay was $12.5 \mathrm{pg} /$ tube.

Plasma PRL was determined by using the rat PRL RIA kit provided by the NIDDK, Bethesda, MD, USA. Each sample (15 $\mu \mathrm{l})$ was assayed in duplicate. Plasma PRL values were expressed in terms of NIDDK rPRLRP-3 preparation. The intra-assay coefficient of variation was $7.6 \%$ at the level of $500 \mathrm{pg} / \mathrm{tube}$. The lowest detectable level was $62.5 \mathrm{pg} /$ tube. All samples were assayed in one radioimmunoassay.

\section{Statistical analysis}

Results were expressed as mean \pm SEM Student's $t$-test or Cochran-Cox test after one-way analysis of variance was used to assess the statistical difference at $\mathrm{P}<0.05$. Fisher's exact probability test (one-tailed test) was used to compare the statistical difference in the ratio between the two groups.

\section{Results}

Experiment 1: Effects of a single injection of progesterone on the length of the diestrous period (Table 1).

In control animals treated with the vehicle on the day of the first estrus, 13 out of 25 (52\%) showed diestrous vaginal smears lasting for more than 9 days with the mean of $11.5 \pm 0.6$ (S.E.M., $n=13$ ) (Table 1). The diestrous period was extended for more than 10 days in all rats by progesterone administration at the dosage level of more than $2.5 \mathrm{mg}$ per $100 \mathrm{~g} \mathrm{B.W}$. on the first estrous day.

Table 1. Effects of a single injection of progesterone on the length of the diestrous period in the first and the third estrous cycle in rats

\begin{tabular}{clccc}
\hline \hline $\begin{array}{c}\text { Stage } \\
\text { of injection }\end{array}$ & $\begin{array}{c}\text { Dose } \\
\mathrm{mg} / 100 \mathrm{~g} \\
\mathrm{BW}\end{array}$ & $\begin{array}{c}\text { Number } \\
\text { of } \\
\text { animals }\end{array}$ & $\begin{array}{c}\text { Number of animals } \\
\text { with more than } 9 \\
\text { days diestrus }\end{array}$ & $\begin{array}{c}\text { Mean diestrous } \\
\text { period (days) } \\
\text { (mean } \pm \text { SEM) }\end{array}$ \\
\hline $\begin{array}{c}\text { 1st cycle } \\
\text { estrus }\end{array}$ & 0 & 25 & 13 & $7.6 \pm 0.8$ \\
& 1.25 & 16 & 11 & $9.0 \pm 0.8$ \\
& 2.5 & 23 & 23 & $11.5 \pm 0.3^{* *}$ \\
diestrus & 5.0 & 17 & 17 & $11.7 \pm 0.3^{* *}$ \\
Day 1 & 2.5 & 21 & $19^{*}$ & $11.3 \pm 0.5^{* *}$ \\
Day 2 & 2.5 & 20 & 12 & $9.3 \pm 0.8$ \\
Day 3 & 2.5 & 20 & 10 & $8.4 \pm 0.9$ \\
\hline 3rd cycle & & & & $2.2 \pm 0.1$ \\
estrus & 0 & 10 & 0 & $3.7 \pm 0.4^{* *}$ \\
& 2.5 & 19 & 1 & $6.1 \pm 0.9^{* *}$ \\
& 5.0 & 17 & $6^{*}$ & $11.7 \pm 0.3^{* *}$ \\
diestrus & 7.5 & 19 & & $5.2 \pm 0.5^{* *}$ \\
Day 1 & 7.5 & 9 & 0 & \\
\hline
\end{tabular}

*: significantly different from the rate of respective controls by Fisher's exact probability test at $\mathrm{P}<0.05$.

${ }^{\dagger}$ : significantly different from the rate of $5.0 \mathrm{mg} / 100 \mathrm{~g}$ body weight $(\mathrm{BW})$ in the $3 \mathrm{rd}$ estrous cycle by Fisher's exact probability test at $\mathrm{p}<0.05$.

$* *$ : significantly different from the value of respective controls by student's $t$-test at $\mathrm{P}<0.05$. 
When progesterone $(2.5 \mathrm{mg} / 100 \mathrm{~g} \mathrm{B.W}$.) was administered either on the first day of estrus or on day 1 of diestrus in rats showing the first estrous cycle, the appearance rate of diestrus continuing for more than 9 days was significantly higher than that in rats treated on day 2 or 3 of diestrus $(\mathrm{P}<0.05$, Table 1$)$.

In the third estrus cycle, the administration of progesterone $(7.5 \mathrm{mg} / 100 \mathrm{~g} \mathrm{~B}$.W.) on the day of estrus induced the long diestrous period lasting for more than 9 days in $89.4 \%$ of the treated animals, but no long diestrus appeared after the administration on day 1 of diestrus. The diestrous period was within 8 days in all animals.

Experiment 2: Effects of traumatization on the function of corpora lutea of pseudopregnant rats induced by progesterone treatment (Table 2).

In rats showing the first estrous cycle, the values in each group were combined values from estrous day and day 1 of diestrus, since all of the animals traumatized on either days formed deciduoma. In rats treated with progesterone on either the day of estrus or on day 1 of diestrus in the first estrous cycle, the uterine weight and the concentration of plasma progesterone were significantly high$\mathrm{er}$ in the traumatized group than in the sham-operated group $(\mathrm{P}<0.05)$. Significantly higher $(\mathrm{P}<0.05)$ uterine weight and the plasma progesterone concentration were also obtained in traumatized rats treated with progesterone on the day of the third estrus than in sham-operated animals $(\mathrm{P}<0.05)$. When progesterone was administered on day 1 of diestrus in rats showing the third estrous cycle, however, the mean vaginal diestrous period was 8 days and the plasma progesterone concentration was significantly lower than in rats treated with

Table 2. Effects of traumatization of the uterus on concentrations of plasma progesterone and weight of the uterus on day 9 of diestrus in pseudopregnancy induced by the treatment with progesterone on estrous day (E) or on day 1 of diestrus (D1) in the first and the third estrous cycle in rat

\begin{tabular}{|c|c|c|c|c|c|c|c|}
\hline & \multirow{2}{*}{\multicolumn{2}{|c|}{$\begin{array}{c}\text { progesterone } \\
(\mathrm{mg} / \mathrm{l00g}) \\
\mathrm{BW}\end{array}$}} & \multicolumn{3}{|c|}{ traumatized } & \multicolumn{2}{|c|}{9 days of diestrus } \\
\hline & & & op. & \multicolumn{2}{|c|}{ dcr. } & $\begin{array}{c}\text { uterine } \\
\text { weight (mg) }\end{array}$ & $\begin{array}{l}\text { progesterone } \\
\text { (ng/ml plasma) }\end{array}$ \\
\hline \multicolumn{8}{|c|}{ estrous cycle } \\
\hline \multirow[t]{3}{*}{ lst } & E o & Dl & & & & & \\
\hline & & 2.5 & - & - & (11) & $152.5 \pm 11.8$ & $38.4 \pm 5.8$ \\
\hline & & & + & + & (10) & $1596.7 \pm 197.6^{\mathrm{a}}$ & $63.2 \pm 9.0^{\mathrm{b}}$ \\
\hline \multicolumn{8}{|l|}{$3 r d$} \\
\hline & E & 7.5 & - & - & ( 8$)$ & $236.3 \pm 18.2^{c}$ & $40.3 \pm 3.4^{e}$ \\
\hline & & & + & + & ( 6$)$ & $2318.4 \pm 150.0^{\mathrm{a}}$ & $72.9 \pm 3.7^{\mathrm{b}}$ \\
\hline & D1 & 7.5 & + & - & $(7)^{*}$ & $826.9 \pm 188.3^{\mathrm{d}}$ & $22.0 \pm 1.6^{\mathrm{f}}$ \\
\hline
\end{tabular}

op: $(+)$ and (-) indicate operation and sham-operation for traumatization performed on day 3 of diestrus, respectively.

dcr: $(+)$ and $(-)$ indicate positive and negative decidual cell reaction observed on day 9 of diestrus, respectively.

Number of animals are given in parentheses.

Values are mean \pm SEM.

*: Number of animals in which vaginal diestrus ended within 9 days after progesterone administration.

a, b: significantly different from the value of respective controls at $\mathrm{P}<0.05$ (a, Cochran-Cox test; $\mathrm{b}$, Student's $t$-test).

c vs d, e vs f: significantly different at $\mathrm{P}<0.05$ (c vs d, Cofhran-Cox test; e vs $\mathrm{f}$, Student's $t$-test). 
Table 3. Daily changes in prolactin secretion on day 2 of diestrus of the estrus cycle in animals injected with progestrene on estrous day (E) or day 1 of diestrus (D1) in the first and the third estrous cycle in rats

\begin{tabular}{|c|c|c|c|c|c|}
\hline & \multirow{3}{*}{\multicolumn{2}{|c|}{$\begin{array}{c}\text { progesterone } \\
\text { treatment } \\
\text { stage dose } \\
(\mathrm{mg} / 100 \mathrm{~g} \mathrm{BW})\end{array}$}} & \multicolumn{3}{|c|}{ concentrations of plasma prolactin $(\mathrm{ng} / \mathrm{ml})$} \\
\hline & & & \multicolumn{3}{|c|}{ time of day } \\
\hline & & & 05:00 & $12: 00$ & 18:00 \\
\hline \multicolumn{6}{|c|}{ estrous cycle } \\
\hline lst & $\mathrm{E}$ & 2.5 & $50.1 \pm 9.0(7)^{*}$ & $13.5 \pm 1.0(7)$ & $32,5 \pm 3.3(5)^{\dagger}$ \\
\hline \multirow[t]{3}{*}{$3 \mathrm{rd}$} & E & 2.5 & $16.2 \pm 1.3(5)$ & $14.7 \pm 1.9(5)$ & $9.5 \pm 1.5(5)$ \\
\hline & $\mathrm{E}$ & 7.5 & $75.5 \pm 15.8(5)^{*}$ & $15.4 \pm 0.7$ & $20.3 \pm 1.0(5)^{\dagger}$ \\
\hline & D1 & 7.5 & $14.4 \pm 1.8(6)$ & $17.8 \pm 0.6(4)$ & $13.3 \pm 1.6(4)$ \\
\hline
\end{tabular}

Values are mean \pm SEM.

Number of animal are given in paretheses.

${ }^{*},{ }^{\dagger}$ : significantly different from the value at $12: 00 \mathrm{~h}$ of the same treated group at $\mathrm{P}<0.05$

(a, Cochran-Cox test; b, Student's $t$-test).

progesterone on the day of the third estrus $(\mathrm{P}<0.05$, Table 2).

Experiment 3: Daily changes in PRL secretion on day 2 of long diestrous period induced by progesterone (Table 3).

Plasma concentrations of PRL in pubertal rats injected with progesterone $(2.5 \mathrm{mg} / 100$ g B.W.) on the day of the first estrus were higher at 05:00 and 18:00 hr than at 12:00 hr $(\mathrm{P}<0.05)$. In the third estrous cycle, however injection of progesterone $(2.5 \mathrm{mg} /$ $100 \mathrm{~g}$ B.W.) on the day of estrus or $(7.5$ $\mathrm{mg} / 100 \mathrm{~g} \mathrm{~B}$.W.) on day 1 of diestrus did not induce PRL surge at 05:00 and 18:00 hr. When rats showing the third estrous cycle were injected with $7.5 \mathrm{mg}$ per $100 \mathrm{~g} \mathrm{~B}$.W. of progesterone on the day of estrus, the plasma PRL concentration at 05:00 and 18:00 hr were also significantly higher than at 12:00 hr $(\mathrm{P}<0.05)$.

\section{Discussion}

The present results indicate that administration of progesterone induced pseudopregnancy more effectively in the first estrous cycle than in the third estrous cycle (Table 1, 2,3 ). The dose of progesterone used in the present experiments $(7.5 \mathrm{mg} / 100 \mathrm{~g} \mathrm{BW})$ for rats showing the third estrous cycle is the same as that used in the adult rat in the previous workers (Everett, 1963; Rothchild and Schubert, 1963; de Greef and Zeilmaker, 1978; Murakami et al., 1980; Luque and Castro-Vaquez, 1983). In rats showing the first estrous cycle, only one third of progesterone dosage in the third estrous day (2.5 $\mathrm{mg} / 100 \mathrm{~g} \mathrm{~B}$.W.) was required for inducing daily changes in PRL secretion and consequently, for forming the functional corpus luteum, indicating that the rats showing the first estrous cycle is susceptible to progesterone for occurring the pseudopregnancy. The appearance rate of pseudopregnancy after the administration of progesterone on day 1 of diestrus in the rat showing the first estrous cycle was also higher than that in the vehicle treated controls, whereas the treatment on day 1 of diestrus in the rat showing the third estrous cycle failed to increase the appearance rate (Table 1).

Our previous report in pubertal rats revealed that progesterone administered within 2 days after ovariectomy on the first estrous day could induce the nocturnal PRL surge (Tomogane and Yokoyama, 1989). PRL is well known to play an essential role for inducing the functional corpus luteum in 
the rat (Rothchild, 1981). Exposure of the newly formed corpus luteum to PRL before noon on day 2 of diestrus is indispensable for its function (Nikitovitch-Weiner and Everett, 1958; Malven, 1969; Döhler and Wuttke, 1974). The present results, therefore, suggest that the susceptive period of the corpus luteum to PRL in pubertal rats showing the first estrous cycle would be similar to the period in adult rats reported by previous workers (Nikitovitch-Weiner and Everett, 1958; Malven, 1969; Döhler and Wuttke, 1974).

The present results (Table 3 ) are consistent with the previous findings demonstrating that pubertal rats have a high susceptibility of the mechanism controlling the nocturnal surge of PRL to progesterone (Tomogane and Yokoyama, 1989). In addition, when progesterone administration in the morning of the estrous day was able to induce daily change of PRL secretion, the elevation in plasma PRL level immediately after the administration occurred (de Greef and Zeilmaker, 1987; Murakami et al., 1980). This immediate elevation was also induced by small dosage of progesterone on estrous day in pubertal rats than in adult rats $(H$. Tomogane, K. Mizoguchi, A. Yokoyama, unpublished data). These results thus suggest that the difference in the appearance rate of the progesterone-induced pseudopregnancy between the first and the third estrous cycle would be ascribed to the difference in the sensitivity of the hypothalamus controlling PRL secretion in response to progesterone.

The long diestrous period lasting for more than 9 days in the first estrous cycle was observed in about a half of the pubertal animal treated with the vehicle (Table 1). This rate is the same as in pubertal animals receiving no treatment (Tomogane et al., 1987) or the animals which vaginal smears were not taken for 3 days after vaginal opening (H. Tomogane, unpublished data). Similar long diestrous period was also observed in the first estrous cycle subsequent to pregnant mare's serum gonadotrophin (PMSG)-induced first ovulation and the appearance rate of long diestrous period increased with advancing age of PMSG administration from 22 to 28 days of age (Tomogane and Yokoyama, 1990). Then, in the second estrous cycle after the first PMSG-induced estrous cycle, we never observed the estrous cycle consisting of the diestrous period as pseudopregnancy (Tomogane and Yokoyama, 1990). It has been demonstrated that daily changes in PRL secretion caused by cervical stimulus appears firstly at 25 days of age in immature rats (Smith and Ramaley, 1978). The action of progesterone to induce daily changes of PRL secretion was less sensitive in adult cyclic rats in comparison with pubertal cyclic rats (Tomogane and Yokoyama, 1989). Therefore, an appearance of the long diestrus in rats showing the first estrous cycle could be due to the change in the responsiveness of hypothalamus to progesterone with the maturation of the individual animal.

The present results also confirmed the previous finding that the uterine deciduoma formed increased the level of plasma progesterone (Hashimoto and Weist, 1969; Nuti et al., 1975). It is likely that PRL-like hormone produced by the decidual tissue would exist in pubertal rats as well as the adult rat (Jayatilak et al., 1984; Herz et al., 1986) and that the deciduoma would prevents the production of the luteolytic substance (Castrancane and Shaikh, 1976; Nanes et al., 1983).

In summary, the present results together with previous ones (Tomogane and Yokoyama, $1989 ; 1990)$ suggest the possible sequence inducing the long diestrus in the first estrous cycle in the rat: the prolactin secretion was initiated by smaller amount of progesterone compared with the adult rat because of the high sensitivity to progesterone. PRL thus stimulates further secretion 
of progesterone from the corpus luteum, the latter hormone in turn stimulating the secretion of PRL.

\section{Acknowledgment}

We are grateful to Dr. S. Raiti, National Hormone and Pituitary Program, NIDDK, Bethesda, MD, USA, for supplying rPRLRIA kit.

\section{References}

Castracane VD, Shaikh AA (1976) Effect of decidual tissue on the uterine production of prostaglandins in pseudopregnant rats. $J$ Reprod Fert 46: 101-104.

Döhler KD, Wuttke W (1974) Total blockade of phasic pituitary prolactin in rats: Effect on serum $\mathrm{LH}$ and progesterone during the estrous cycle. Endocrinology 94: 1595-1960.

Everett JW (1963) Pseudopregnancy in the rat from brief treatment with progesterone: Effect of isolation. Nature 4881: 695-696.

Hashimoto I, Wiest WG (1969) Correlation of the secretion of ovarian steroids with function of a single generation of corpora lutea in the immature rat. Endocrinology 84: 873-885.

Herz Z, Khan I, Jayatilak PG, Gibori G (1986) Evidence for the secretion of decidual luteotropin: A prolactin-like hormone produced by rat decidual cells. Endocrinology 118: 2203-2209.

Jayatilk PG, Glaser LA, Warshaw ML, Herz Z, Gruber JR, Gibori G (1984) Relationship between luteinizing hormone and decidual luterotropin in the maintenance of luteal steroidgenesis. Biol Reprod 31: $556-564$.

de Greef WJ, Zeilmaker GH (1978) Serum prolactin concentration during hormonally induced pseudopregnancy in the rat. Endocrinology 105: 195-199.

Luque EH, Castro-Vazquez A (1983) Sensory mechanisms involved in the induction of pseudopregnancy by progesterone: Increased sensitivity to stimulation of the pudendal sencory field. Endocrinology
113: 385-390.

Malven PV (1969) Luteotrophic and luteolytic response to prolactin in hypothysectomized rats. Endocrinology 84: 1224-1229.

Murakami N, Takahashi M, Suzuki Y (1980) Induction of pseudopregnancy and prolactin surges by a single injection of progesterone. Biol Reprod 22: 253-258.

Nanes MS, Morishige WK, Rothchild I (1983) The role of decidual tissue in the development of the dependency on luteinizing hormone in the rat corpus luteum. Endorinology 112: 2181-2186.

Nikitovitch-Weiner M, Everett JW (1958) Comparative study of luteotropin secretion by hypophysial autotransplants in the rat: Effet of site and stages of the oestrous cycle. Endocrinology 62: 522-532.

Nuti KM, Sridharan BN, Meyer RK (1975) Reproductive biology of PMSG-primed immature female rats. Biol Reprod 13: 38-44.

Rothchild I (1981) The regulation of mammalian corpus luteum. Recent Prog Horm Res 37: 183-298.

Rothchild I, Schubert R (1963) Corpus luteum-pituitary relationship: induction of pseudopregnancy in the rat by progesterone. Endocrinology 72: 968-972.

Smith MS, Ramaley JA (1978) Development of ability to initiate and maintain prolactin surge induced by uterine cervical stimulation in immature rats. $E n$ docrinology 102: 351-357.

Tomogane H, Ikeda M, Yokoyama A (1987) Daily changes in concentration of plasma prolactin during diestrous period of the first estrous cycle in pubertal rats. In: Kyoto Prolactin Conference, vol. 2 (Hoshino $\mathrm{K}$ ed.), Kyoto University Faculty of Medicine, Kyoto, pp41-50.

Tomogane H, Yokoyama A (1989) Development of progesterone dependency in the appearance of nocturnal prolactin surge in immature rats. $J$ Reprod Fertil 85: 503-509.

Tomogane H, Yokoyama A (1990) Positive feedback relationship between progesterone and daily change of prolactin secretion that develops functional corpora lutea in PMSG-induced first oestrous cycle in prepubertal rats. Comp Biochem Physiol 95A: 185-188. 


\title{
プロジェステロンの偽妊娠誘起作用について 一腟開口後の初回発情ラットと第 3 回目発情周期ラットとの比較一
}

\author{
友金 弘・横山 昭 \\ 名古屋大学農学部家畜繁殖学教室, $\mathrm{T} 464-01$ 名古屋市千種区不老町
}

幼若ラットの初回発情周期時に高頻度で認められる偽 妊娠様発情休止期の発生機序を明らかにする一端として, 腟開口後の初回発情周期時と 3 回目発情周期時との間で プロジェステロンの偽妊娠誘起効果を比較した。

初回発情周期を示す幼若動物では体重 $100 \mathrm{~g}$ 当たり $2.5 \mathrm{mg}$ のプロジェステロンを発情日あるいは発情休止 期 1 日目に投与するとすべての動物で発情休止期は 9 日 以上となり, 血中プロラクチン濃度は日内变動を示した。
黄体は機能化し, 血中プロジェステロンは偽妊娠様の高 濃度を示し, 脱落膜腫形成によりさらに上昇した。一方, 3 回目の発情周期時のラットでは同様の効果を得るため のプロジェステロン量は増加し, 初回発情周期時の 3 倍 量を必要とした。

これらの結果は, 幼若動物の初回発情周期時にはプロ ジェステロンが偽妊娠様発情休止期を効率よく誘起する ことを示す。 